\title{
Permeability of biological and synthetic molecules through dentine
}

\author{
C.T. HANKS, J.C. WATAHA, R.R. PARSELL, S.E. STRAWN \\ and J.C. FAT The University of Michigan School of Dentistry, Ann Arbor, MI, U.S.A.
}

\section{Summary}

The diffusion through dentine by a number of biological and synthetic molecules, including resins and dyes, is reported. In vitro measurements were derived by experiments with a modified 'split-chamber device'. Diffusion was found to be indirectly proportional to dentine thickness for all molecules. Permeability of water-soluble molecules and ethanol-soluble molecules was proportional to the molecular weights, except for fluorescein, hydrogen peroxide $\left(\mathrm{H}_{2} \mathrm{O}_{2}\right)$ and urethane dimethacrylate. The resin components tested are not soluble enough in an aqueous medium to diffuse through $0.5 \mathrm{~mm}$ dentine at sufficient concentrations to cause cytotoxicity to pulpal cells.

\section{Introduction}

Long-term dental pulp reactions (i.e. weeks to months) in response to restorative materials (Avery, 1975; Stanley, Bowen \& Folio, 1979; Heys et al., 1982), as well as to bacteria and their products (Brännström \& Nyborg; 1972; Bergenholtz et al., 1982; Varpio, Warfvinge \& Norén, 1990) have been reported in the literature. However, early effects (i.e. minutes to hours) of dental materials have not been well documented except under special conditions. In order to understand how synthetic and biological materials cause physiological and pathological changes in cells, in vitro studies have been useful. Previous culture assays for cytotoxicity of materials to mammalian tissues have been performed with cell monolayers and have focused only on measurements of biological activity (e.g. DNA and protein synthesis, enzyme activity, vital dye and ${ }^{51} \mathrm{Cr}$ uptake and release, etc.) in response to restorative materials (Wataha et al., 1994) or bacteria or bacterial products (Dahlen \& Bergenholtz, 1980). In our studies, a device modelled largely after the split-chamber device used by Pashley and colleagues to study convection and diffusion permeability in dentine (Outhwaite, McKenzie \& Pashley, 1974) has been introduced as the second step in this two step protocol. In this manner, we are attempting to begin risk assessment of these materials.

Although the concentrations of the solute molecules and the cellular responses are undoubtably modified in vivo by complexity of tissue structures, molecules in the vicinity capable of binding to other molecules, the state of the vascularity of pulp tissues, and a variety of paracrine and hormonal influences, the in vitro approach which includes a dentine barrier should help us understand how diffusion may affect penetration of molecules to pulpal tissue. The objectives of the present studies were: (i) to measure concentrations of resin components, blood proteins, peptides, dyes 
and other molecules by a common laboratory method, ultraviolet and visible light spectrophotometry; and (ii) to determine diffusion permeability of these molecules through human molar dentine disks for which the thickness and hydraulic conductance values were known.

\section{Methods}

\section{Assays for test materials}

A standard was developed for light absorbance vs. concentration for each molecule tested (Tables $1 \& 2$ ) by serially diluting stock solutions of known concentrations down to $2 \mu \mathrm{g} / \mathrm{ml}$ for each test material. Only the linear portion of each curve was used. Absorbance readings were directly proportional to the concentrations of the solutes. Multiple aliquots of both test and standard solutions were then read in a DU-64 spectrophotometer*. For proteins, the Micro-BCA assay† was performed.

\section{Preparation of dentine disks}

Freshly extracted non-carious human molars with a crown diameter of at least $9 \mathrm{~mm}$ were cleaned of tissue and debris and washed with $70 \%$ ethanol to disinfect the surface. The dentine disks were cut to various thicknesses in cross-section just above the pulpal horns. Only one disk was taken from each tooth. Each disk was cut at $230 \mathrm{rev} / \mathrm{min}$ with a low-speed saw $\ddagger$, using a 4 inch diameter diamond-wafering blade $\$$, followed by hand-sanding with 800 grit silicon carbide paper. The disks were treated with $0.5 \mathrm{M}$ EDTA ( $\mathrm{pH} \mathrm{7.4)} \mathrm{for} 2 \mathrm{~min}$, hydrated $3 \mathrm{~min}$ in each of three different wells of PBS to stop chelation and then were stored in $70 \%$ ethanol in a vacuum jar (20 psi) to displace air bubbles with ethanol. Just before use, disk thicknesses and hydraulic conductance values $\left(\mathrm{Lp} ; \mu \mathrm{g} / \mathrm{ml}^{-1} \min ^{-1} \mathrm{~cm} \mathrm{H}_{2} \mathrm{O}^{-1}\right.$ ) were determined for each disk.

\section{Diffusion chamber}

The diffusion chamber, fabricated from polycarbonate, was adapted from the 'splitchamber' device introduced by Outhwaite, McKenzie \& Pashley (1974). The diffusate established a gradient through a 'hydrated' dentine disk separating the two chambers (Fig. 1). The centre area $\left(0 \cdot 29 \mathrm{~cm}^{2}\right)$ of each dentine disk was isolated by means of a silicone O-ring $\llbracket$. There were two major adaptations to the 'split-chamber'. The first was the blocking of the central chamber under the dentine disk by vinyl polysiloxane impression material**, so that the chamber volume was only $45 \mu \mathrm{l}$. The second adaptation was to make the top reservoir airtight to prohibit evaporation. Tubing was fitted to the top reservoir to introduce the test solution.

\section{Diffusion studies}

Either water-soluble or ethanol-soluble molecules were introduced in a solvent to one surface of a hydrated dentine disk in the 'diffusion chamber' (Fig. 1), and a constant flow of solvent across the opposite side of the disk carried the diffusate to the collection

* Beckman Instruments Inc., Fullerton, CA, U.S.A.

† Pierce, Rockford, IL, U.S.A.

‡ Model 650 Low Speed Diamond Wheelsaw, Southbend Technology, Inc., Temple City, CA, U.S.A.

§ C-153; grit 320; Mager Scientific Inc., Dexter, MI, U.S.A.

If O-Rings Inc., Los Angeles, CA, U.S.A.

** Reprosil ${ }^{\circledR}$, L.D. Caulk Co., Milford, CN, U.S.A. 


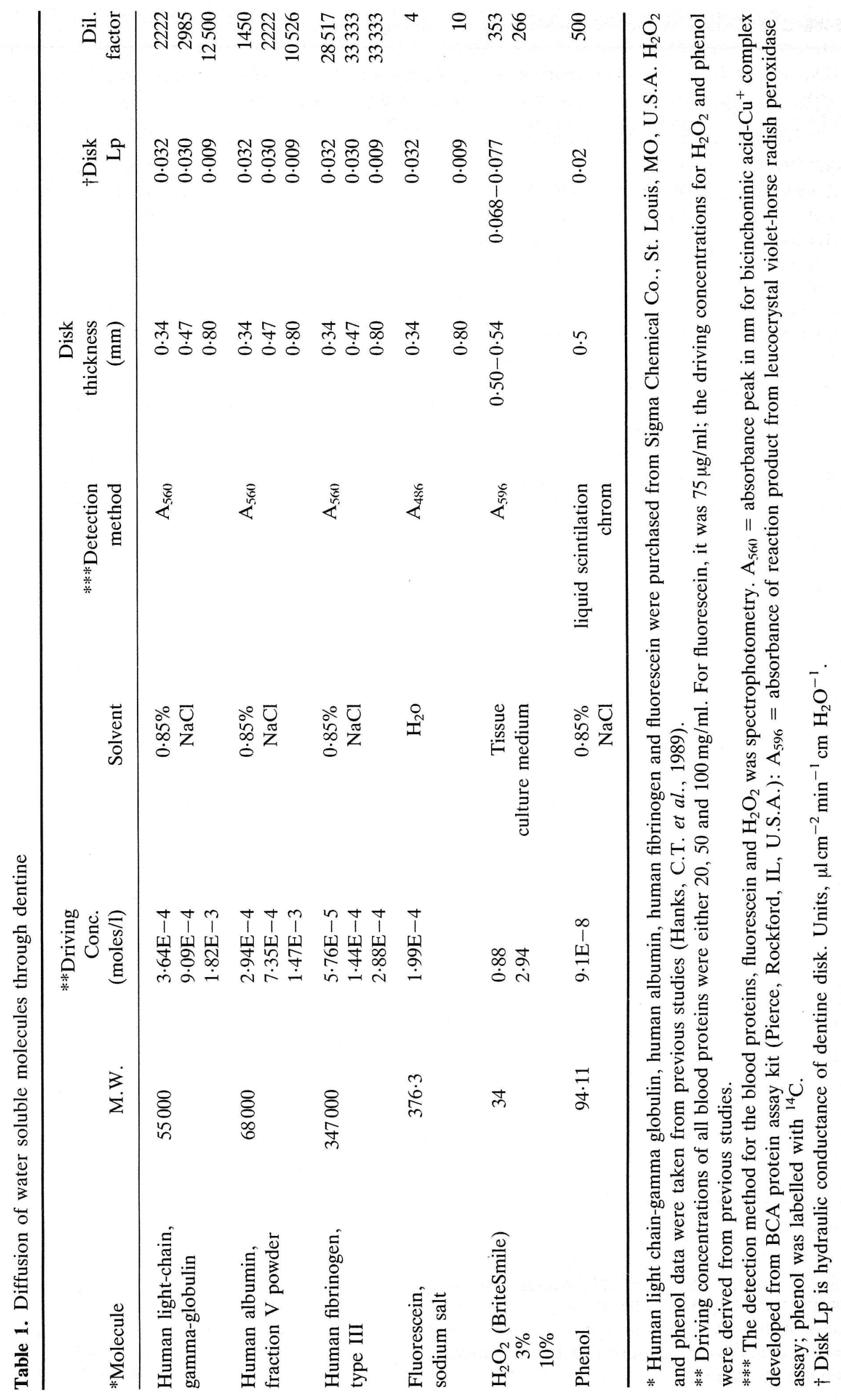


Table 2. Diffusion of ethanol soluble molecules through dentine

\begin{tabular}{lccrrrr}
\hline *Molecule & M.W. & $\begin{array}{r}\text { Driving } \\
\text { Conc. } \\
(\mathrm{mol} / \mathrm{l})\end{array}$ & $\begin{array}{r}\text { Detection } \\
\text { wavelength } \\
(\mathrm{nm})\end{array}$ & $\begin{array}{r}\text { Disk } \\
\text { thickness } \\
(\mathrm{mm})\end{array}$ & $\begin{array}{r}\text { **Disk } \\
\text { Lp }\end{array}$ & $\begin{array}{r}\text { Dil. } \\
\text { factor }\end{array}$ \\
\hline bisGMA & $512 \cdot 65$ & $0 \cdot 5$ & 280 & $0 \cdot 48$ & $0 \cdot 046$ & 1515 \\
UDMA & $498 \cdot 69$ & $0 \cdot 5$ & 225 & $0 \cdot 43$ & $0 \cdot 045$ & 625000 \\
E-BPA & $452 \cdot 59$ & $0 \cdot 02$ & 230 & $0 \cdot 47$ & $0 \cdot 032$ & 500 \\
DHEpT & $420 \cdot 13$ & $0 \cdot 025$ & 260 & $0 \cdot 47$ & $0 \cdot 029$ & 1389 \\
DMAEM & $352 \cdot 1$ & $0 \cdot 1$ & 226 & $0 \cdot 45$ & $0 \cdot 039$ & 263 \\
BGE-BPA & $340 \cdot 45$ & $0 \cdot 1$ & 228 & $0 \cdot 48$ & $0 \cdot 029$ & 1250 \\
TEGDMA & 286.36 & $0 \cdot 1$ & 225 & $0 \cdot 46$ & $0 \cdot 050$ & 571 \\
HDDM & $286 \cdot 36$ & $0 \cdot 005$ & 226 & $0 \cdot 41$ & $0 \cdot 053$ & 109 \\
BPA & $228 \cdot 31$ & $1 \cdot 0$ & 280 & $0 \cdot 43$ & $0 \cdot 045$ & 2564 \\
GMA & $142 \cdot 17$ & $0 \cdot 1$ & 220 & $0 \cdot 47$ & $0 \cdot 047$ & 222 \\
\hline
\end{tabular}

* In the above table, the following molecules, each dissolved in $95 \%$ ethanol, are arranged according to molecular weights: bis glycidyl ether of bis phenol A (BGE-BPA); bis glycidyl methacrylate (bisGMA); bis phenol A (BPA); ethoxylated bis phenol A dimethacrylate (E-BPA); glycidyl methacrylate (GMA); 1,6 hexane diol dimethacrylate (HDDM); N,N dihyroxyethyl-p-toluidine (DHEpT); triethylene glycol dimethacrylate (TEGDMA); urethane dimethacrylate (UDMA), all from Esschem, Essington, PA, U.S.A. N,N dimethylaminoethyl methacrylate (DMAEM) was purchased from KochLight Laboratories, Colnbrook, Buck, U.K.

** Hydraulic conductance of dentine disks. Units are $\mu \mathrm{cm} \mathrm{cm}^{-2} \mathrm{~min}^{-1} \mathrm{~cm} \mathrm{H}_{2} \mathrm{O}^{-1}$.

device. In these studies, there was no convection of solvent through the dentine disks into the lower chamber. For water soluble molecules (Table 1), one dentine disk for each of three thicknesses of dentine was used. The disk thicknesses were $0.34 \mathrm{~mm}$, $0.47 \mathrm{~mm}$ and $0.8 \mathrm{~mm}$, with $\mathrm{Lp}$ values of $0.032,0.030$ and 0.009 , respectively. The study was planned so that once a disk was in place in the diffusion chamber, it was not moved. Thus, the relative porosity (as measured by the Lp) remained the same for each dentine disk throughout the study.
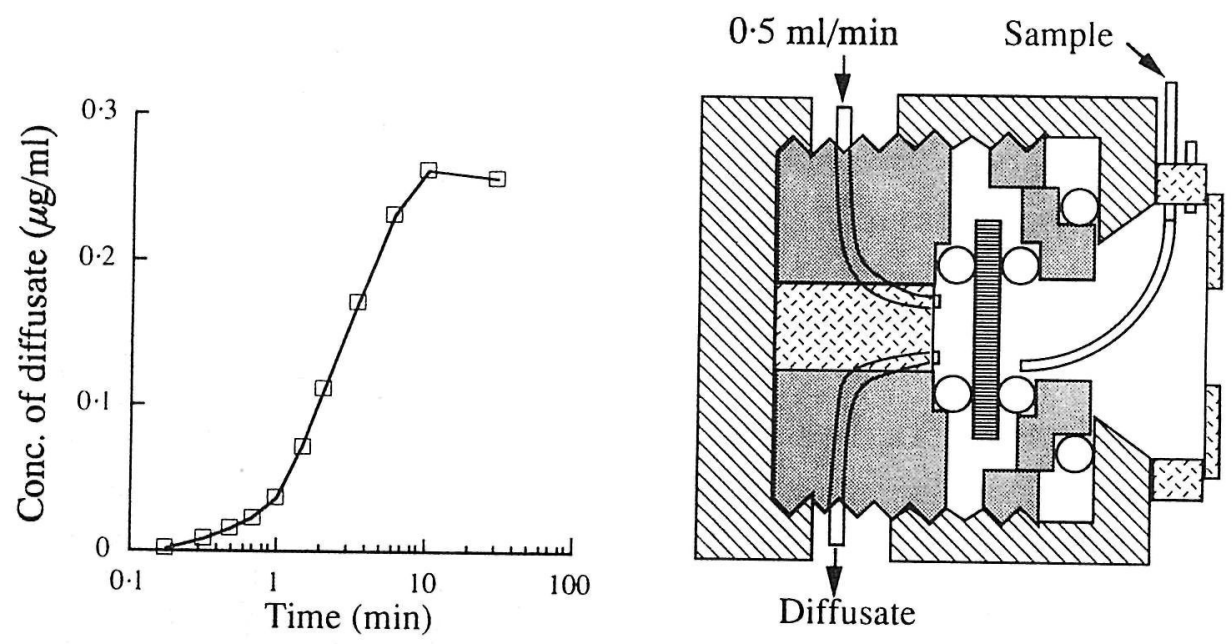

Fig. 1. Graph of curve of establishment of diffusion gradient (left) and diffusion chamber (right), modified from split-chamber device (Outhwaite et al., 1974). The diffusion gradient was usually established within $10-15 \mathrm{~min}$ in a 'hydrated' dentine disk. At that point, the curve plateaued: the central area $\left(0 \cdot 29 \mathrm{~cm}^{2}\right)$ of the dentine disk in the diffusion chamber was isolated by $\mathrm{O}$-rings. The lower chamber volume was $45 \mu \mathrm{l}$. 
Each of three blood proteins (either human light-chain gamma globulin, albumin or fibrinogen) was dissolved in $0.85 \% \mathrm{NaCl}$ (Table 1) and placed in the top reservoir of the diffusion chamber (Fig. 1), at one of three concentrations (either 20000, 50000 or $100000 \mu \mathrm{g} / \mathrm{ml})$. The solvent solution was slowly circulated across the opposite side of the dentine disk at $0.5 \mathrm{ml} / \mathrm{min}$, and serial $100 \mu \mathrm{l}$ aliquots of the solution containing the diffusates were measured spectrophotometrically. The plasma protein concentrations in the diffusates were determined indirectly by using the micro-BCA protein assay*. Fluorescein was also applied to the dentine disk (top reservoir), but at only one concentration $(75 \mu \mathrm{g} / \mathrm{ml})$. The concentration of the fluorescein diffusate was determined directly by VIS spectrophotometry.

Because the resin components are minimally soluble in aqueous solvents, 95\% ethanol was used as the solvent for diffusion studies (Table 2). Only one disk was used for each resin component. The disk thicknesses ranged from $0.41-0.48 \mathrm{~mm}$ and the $\mathrm{Lp}$ values ranged from $0 \cdot 029-0 \cdot 053$. Each disk was tested by water pressure for leakage, cracks and hydration of the tubules before test solutions were applied. The dentinal tubules were then completely filled with $95 \%$ ethanol. The spectrophotomer was zeroed with $95 \%$ ethanol with all tubing $\left(\right.$ Tygon $\left.^{\circledR}\right) \dagger$ in place prior to starting the diffusate through the flow cell. The flow rate of ethanol through the lower chamber to capture the diffusate was $0.5 \mathrm{ml} / \mathrm{min}$. The tubing led directly to a flow tube in the spectrophotometer. After each experiment, all parts were rinsed in ethanol. The dentine disk was cleaned by ethanol filtration while still in the diffusion chamber under the manometer column $(180 \mathrm{~cm})$ until the Lp returned to normal.

\section{Calculations}

The permeability coefficient of each molecule was used to estimate diffusibility for various dentine thicknesses in the absence of smear layers:

$P=\frac{\mathrm{JS}}{(\mathrm{C} 1-\mathrm{C} 2) \mathrm{A}}$

Where $P=$ permeability coefficient in $\mathrm{cm} / \mathrm{min}$; Js $=$ net solute flux in $\mu \mathrm{mol} / \mathrm{cm}^{2} / \mathrm{min}$; $\mathrm{C} 1=$ conc. of solute applied to the top of the gradient in $\mu \mathrm{mol} / \mathrm{cm}^{3} ; \mathrm{C} 2=$ conc. of solute at bottom of gradient in $\mu \mathrm{mol} / \mathrm{cm}^{3} ; \mathrm{A}=$ surface area of dentine $\left(0.29 \mathrm{~cm}^{2}\right.$ in this study).

\section{Results}

The diffusion experiments were developed so that the flux of molecules could be measured under standard conditions in slices of human molar dentine, and the effects of dentine thickness and molecular size on this flux could be determined. The concentrations of water-soluble solutes in the diffusates were measured after diffusion gradients were established (Fig. 1). The diffusion of three blood proteins and fluorescein were measured at multiple dentine thicknesses. In Fig. 2 , the permeability coefficients $(P$, $\mathrm{cm} / \mathrm{min}$ ), were calculated for these proteins, fluorescein and phenol, and were plotted as average values against dentine thickness. For all five molecules with various driving concentrations, $P$ was proportional to dentine thickness. The slope of the curves for all molecules except fibrinogen were similar. For fibrinogen, the slope was steeper

* Pierce, Rockford, IL, U.S.A.

$\dagger$ Norton Performance Plastic Corp., Akron, OH, U.S.A. 


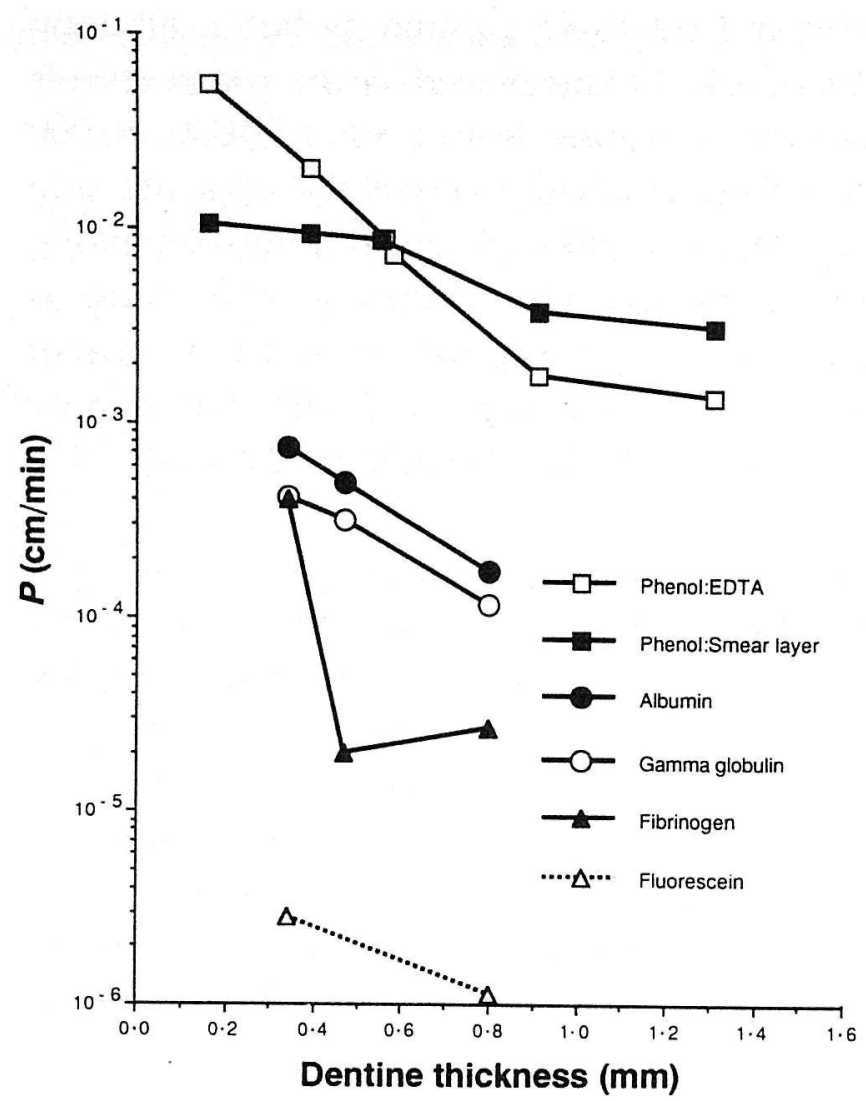

Fig. 2. Permeability coefficients $(P, \mathrm{~cm} / \mathrm{min})$ derived from flux measurements of phenol (on dentine disks with and without smear layers), albumin, light-chain gamma globulin, fibrinogen and fluorescein, as a function of the thickness of the dentine disk.

$(-0.009 \mathrm{~cm} / \mathrm{min} / \mathrm{mm})$ than for other molecules (approximately $-0.013 \mathrm{~cm} / \mathrm{min} / \mathrm{mm}$ ) between the dentine thicknesses of $0.34-0.47 \mathrm{~mm}$, and then plateaued between $0.47-$ $0.8 \mathrm{~mm}$. Phenol reached its lowest level of permeability at about $0.9 \mathrm{~mm}$ dentine thickness and plateaued between $0.9-1.3 \mathrm{~mm}$ thickness. There was good correlation between molecular weight and $P$ for all molecules except fluorescein, for which $P$ was substantially reduced.

Ignoring $\mathrm{H}_{2} \mathrm{O}_{2}$ and fluoroescein in Fig. 3, $P$ values for the three blood proteins and

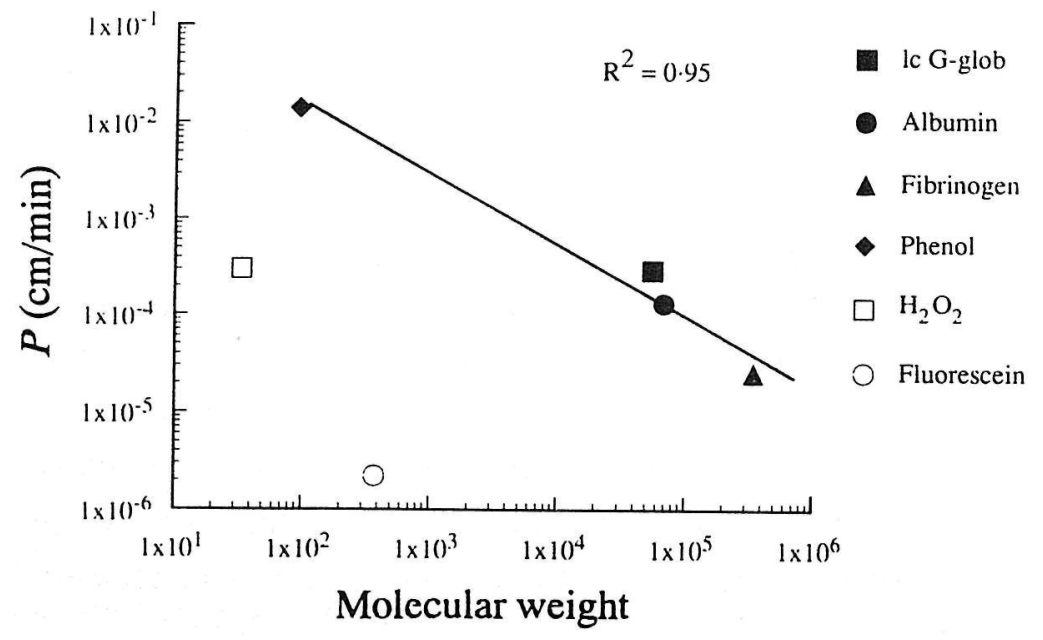

Fig. 3. Comparison of $P$ values for three serum proteins, phenol, $\mathrm{H}_{2} \mathrm{O}$ and fluorescein in $0 \cdot 49-0.5 \mathrm{~mm}$ dentine disks. The line represents line of best fit for all compounds except fluorescein and $\mathrm{H}_{2} \mathrm{O}_{2}$. 


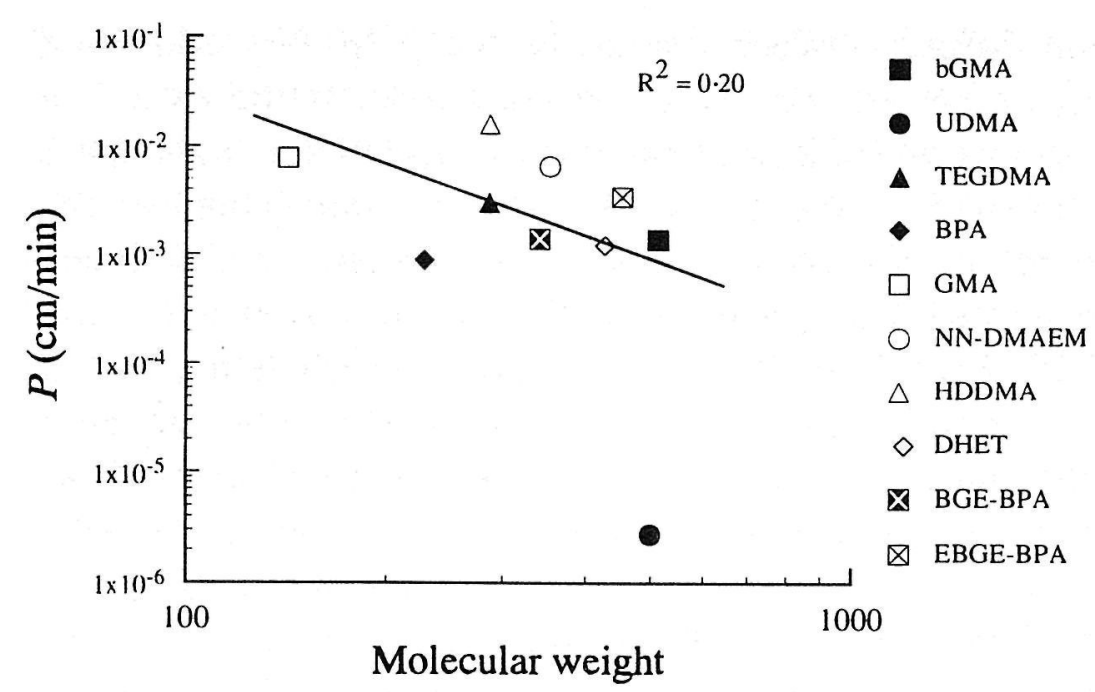

Fig. 4. Comparison of $P$ values for resin components in $95 \%$ ethanol in $0.45 \mathrm{~mm}$ dentine disks. The line represents line of best fit for all compounds except UDMA.

phenol correlated well $\left(r^{2}=0.95\right)$ with the molecular weights. The dentine thicknesses of all dentine slices in this figure were approximately $0.49 \mathrm{~mm}$. However, $P$ values for both fluorescein and $\mathrm{H}_{2} \mathrm{O}_{2}$ were lower by two and three orders of magnitude, respectively, than would be expected on the basis of molecular weight.

$P$ values for the resin components solubilized in 95\% ethanol and plotted against the molecular weights of these components are shown in Fig. 4. Again, these parameters correlated better for some components than others. The $P$ values and molecular weights for the resin components, excluding UDMA, correlated less $\left(r^{2}=0 \cdot 2\right)$ than for the water soluble molecules. For each component, only one dentine disk with an average thickness of $0.45 \mathrm{~mm}$ was used.

\section{Discussion}

Although human studies and animal usage tests have suggested since the early 1980 s up to the present time that pulpal reactions in restored teeth are the result of bacterial infections and bacterial products because of microleakage of the restoration (Brännström \& Nyborg, 1972; Cox et al., 1982), there do appear to be instances of authentic reactions to dental materials. Nasjleti, Castelli \& Caffessee (1983) showed that when a composite resin $\left(\right.$ Merdonite $\left.{ }^{\circledR}\right) *$ was placed in extracted monkey teeth under low oxygen conditions, and the teeth were re-implanted into the sockets, directly against tissue (periodontal membrane) and without bacterial intervention, this composite resin caused severe chronic inflammation for at least 6 months postoperatively. Dental materials other than resins have been reported to cause reactions in dental pulps of animals after diffusion through dentine (Edwall \& Olgart, 1972; Stanley, Bowen \& Folio, 1979; Hörsted-Bindslev, 1987). Finally, there have been several reports of diffusion of small molecules $\left(\mathrm{H}_{2} \mathrm{O}_{2}\right.$, sodium and urea) through enamel (Seale, McIntosh \& Taylor, 1981), so that dentinal diffusion of dental materials seems to be a valid concern.

Diffusion is a longer-term process than convection, and occurs after crowns, inlays and other restorations have been placed. Depending on the integrity of the smear layer, cavity liner, cement or other adhesive material in closing off the dentinal

\footnotetext{
* American Consolidated Manufacturing Co., Philadelphia, PA, U.S.A.
} 
tubules, more or less solute will diffuse between the cavity and pulp. Not addressed in the present diffusion model, or any of the dentine barrier tests, is the extent of diminution of diffusion by adsorption to walls and contents of the tubules, the degree of binding by blood-derived molecules, and the effect of fluid convection in the direction of pulp to cavity preparation. Molecules derived from cements, cavity liners, dentine bonding agents and restorative materials, as well as bacterial products and blood and tissue-derived peptides, are carried as aqueous diffusion gradients, and at the same time. Thus, there are many opportunities for interaction between these molecules. The starting concentrations depend on the solubility of these materials in water over time. The presence of a smear layer, cavity varnishes and cements blocking the dentinal tubules will have a larger effect on convection (proportional to the radius of the tubules raised to the fourth power) than on diffusion (proportional to the radius squared) (Pashley, 1989). Finally, convection from positive fluid pressure from pulp to the cavity preparation has the ability to reduce molecular concentrations in the diffusate by half in the absence of a smear layer (Matthews \& Pashley, 1992).

The first objective of this study was to determine if spectrophotometry, a technique available in most laboratories, is sufficiently sensitive to allow measurement of concentrations of molecules in either diffusates or filtrates after passage through dentine. In general, radioisotopic methods (radioimmunossay, ELISA, liquid scintillation) as well as gas chromatography are sensitive at the level of picograms $/ \mathrm{ml}$. In comparison, UV and light spectrophotometry are sensitive at the $\mu \mathrm{g} / \mathrm{ml}$ level (Chamberlain, 1987). The MicroBCA assay (Pierce) can detect proteins and peptides in the $1 \mu \mathrm{g} / \mathrm{ml}$ range. Thus, in this study, starting concentrations of proteins of 20,50 and $100 \mathrm{mg} / \mathrm{ml}$ were used and proteins which had been diluted between 2000 and 125000 times (data not shown) in the diffusate were detectable by light spectroscopy. For fluorescein, with a starting concentration of $75 \mu \mathrm{g} / \mathrm{ml}$, dilutions of 2000 times were easily detectable. In a previous study (Hanks et al., 1989), ${ }^{14} \mathrm{C}$-phenol was applied to a $0.5 \mathrm{~mm}$ dentine disk at an extremely low concentration $(0.0091 \mu$ moles $/ 100 \mu \mathrm{l} ; 1 \mu \mathrm{Ci})$ and was detected after being diluted 100-500 times by the diffusion gradient. Greater difficulty in measuring concentrations is anticipated when more than one molecule in a mixed solution must be measured, or when it is necessary to pick one molecule out of a mixed solution, e.g. in molecular binding studies or synergistic/antagonistic studies of two or more molecules. Then, either radioisotope-labelled compounds of known structure or a spetrophotometric method which can identify different species of molecules will be necessary. At present, either HPLC, gas chromatography, or FTIR (Ferracane, 1994) is necessary to identify species of resin components in the solvent. Biological molecules which are radio-labelled are more readily available.

There are several 'dentine barrier' models using human dentine described in the literature (Hume, 1985; Hanks et al., 1988; Meryon \& Brook, 1989). Their advantage is that they demonstrate the effect of dilution of biologically active materials by the dentine diffusion gradient. One of their drawbacks is that they are all in vitro methods which dilute further the diffusate by medium between the dentine and the cell test system. Thus, an exact relationship between concentration and the biological effect cannot be established for a compound or material with these methods. Cells have been cultured on the bottom side of the dentine disk in this laboratory in an attempt to reduce dilution of the diffusate. However, consistency of plating numbers of cells within and across experiments is not possible because of biological variability of dentine and other culturing artefacts. Thus, at the present stage of development, these test 
systems are still best suited for rank-ordering of a series of compounds. Improvements on these methods include reducing the volume of the diffusate chamber to microlitre quantities in order to eliminate arbitrary dilution by nutrient media. Therefore, a two step system is now used. In the first step, concentration ranges which are toxic in monolayer cultures of the cells are determined. In the second step, and as a separate test, solute dilution by dentine diffusion gradients is determined. We have been able to reduce the diffusion chamber to $45 \mu \mathrm{l}$ volume in the present study.

In the study of diffusion through dentine slices, it was decided to normalize the data by expressing it as permeability coefficient $(P)$ for each compound, and to compare $P$ for different compounds under similar conditions. Figure 2 shows that increasing dentine thickness caused a reduction in $P$ for three blood proteins (human albumin, fibrinogen and light-chain gamma globulin), and for fluorescein and phenol. The most permeable plasma protein tested, albumin, had a $P$ value between 1 and $7 \times 10^{-4} \mathrm{~cm} /$ min, depending on the dentine thickness tested. For comparison, Pashley \& Livingston (1978) found the $P$ value of albumin, in Krebs-Ringer-phosphate buffer, after diffusion through $1 \mathrm{~mm}$ human molar acid-etched dentine to be approximately $2.4 \times 10^{-5} \mathrm{~cm} / \mathrm{min}$, but $2.4 \times 10^{-6} \mathrm{~cm} / \mathrm{min}$ in the same dentine with a smear layer. While our measurements were made with EDTA-treated dentine between 0.35 and $0.8 \mathrm{~mm}$ thick, extrapolation of the dentine thickness to $1 \mathrm{~mm}$ in Fig. 2 gives a $P$ value for albumin with this range $\left(9 \times 10^{-5} \mathrm{~cm} / \mathrm{min}\right)$.

In the present study, fibrinogen diffusion did not result in a straight line relationship at dentine thicknesses between 0.34 and $0.8 \mathrm{~mm}$. The $P$ values were drastically reduced at dentine thicknesses between 0.34 and $0.47 \mathrm{~mm}$, perhaps because of steric obstruction of the tubules because of the size of the molecule. However, this was not a system in which fibrin polymerization (clotting) was intentional. Pashley has discussed the issue of adsorption vs. physical entrapment (steric hindrance) of fibrinogen (Pashley, Galloway \& Stewart, 1984a), and has calculated that the size of the molecule $(0.03 \times$ $0.09 \mu \mathrm{m}$ in diameter) allows it to physically block dentinal tubules with diameters of 0.04 to $0.19 \mu \mathrm{m}$, without imposing the clotting cascade. Evidence for blockage was that the removal of fibrinogen from plasma reversed the reduction of Lp seen with whole plasma. Pashley also suggested that as other plasma proteins pass across HA crystals and adsorb to the HA surface, the functional radius of the tubules may be reduced (Pashley et al., 1984b), and thus steric hindrance of the dentinal tubules may be in part a result of adsorption of the molecules to the dentine tubule surface. Other studies in this laboratory have shown that fibrinogen was either sorbed or sterically hindered more than plasma proteins, bacterial peptides or LPS, a molecule approximately 10 times larger than fibrinogen (data not published).

The $P$ values were proportional to the molecular weights of all molecules except fluorescein (Fig. 3). Thus, it does not appear that albumin, light-chain gamma globulin, haemoglobin or phenol were sorbed to a great extent. On the other hand, the $P$ values for fluorescein were disproportionately low at both 0.34 and $0.8 \mathrm{~mm}$ dentine thickness, which strongly suggests that fluorecscein binds to dentine. Pashley and colleagues have further identified several other materials which bind substantially to dentine including calcium, phosphate and fluoride ions (Pashley, 1989), tetracycline (Ciarlone et al., 1988), and parathormone (Pashley, 1988).

The resin components are relatively insoluble in aqueous solutions. In order to solubilize amounts adequate for spectrophotometric identification of solutes in diffusates, $95 \%$ ethanol was used as the solvent. However, for practical purposes the diffusion 
coefficients for solutes in ethanol and solutes in aqueous solutions are similar, and solutes in ethanol appear to function similarly to water-soluble molecules (Cussler, 1984). Except for UDMA, all the $P$ values of the components were between $1 \times 10^{-3}$ and $2 \times 10^{-2}$ (Fig. 4), and had been diluted by $0.45 \mathrm{~mm}$ dentine to between 100 and 2500 times. Had these components been labelled by radioisotopes or had a more sensitive method of detection been used, much lower starting concentrations could have been utilized. In a previous study (Hanks et al., 1991), most of these substances were shown to be toxic in the 1-100 $\mu$ moles/l range. The inhibitory dose for DNA synthesis in half the cells $\left(\mathrm{ID}_{50}\right)$ for bisGMA equalled approximately $13 \mu$ moles/1 $(6.7 \mu \mathrm{g} / \mathrm{ml})$. Dilution of bisGMA by the diffusion gradient in $0.45 \mathrm{~mm}$ dentine disks was about 1500 times in the present study. Therefore, if the effects of the smear layer, odontoblasts, capillaries or pulp fluid pressure are disregarded, for the bisGMA concentration in the diffusate to reach the $\mathrm{ID}_{50}$ level, the bisGMA starting concentration in the cavity preparation in dentine $0.45 \mathrm{~mm}$ thick would have to be about $20 \mathrm{mmoles} / 1$ $(10 \mathrm{mg} / \mathrm{ml})$. However, bisGMA is only soluble to about $48.5 \mu \mathrm{moles} / \mathrm{l}(25 \mu \mathrm{g} / \mathrm{ml})$ in tissue culture medium. Therefore, in order for bisGMA to be toxic, little or no dilution from its limit of aqueous solubility could occur. Since dentine disks $0.45 \mathrm{~mm}$ in thickness diluted the bisGMA 1500 times, the dentine barrier would have to be much thinner than $0.4 \mathrm{~mm}$, or absent, for a cytotoxic reaction by cells.

Likewise for triethylene glycol dimethacylate (TEGDMA), the $\mathrm{ID}_{50}$ is $66 \mu$ moles/l $(\sim 19 \mu \mathrm{g} / \mathrm{ml})$ (Hanks et al., 1991). The practical limit of TEGDMA solubility in tissue culture medium was about $450 \mu$ moles $/ 1(\sim 129 \mu \mathrm{g} / \mathrm{ml})$, when it was prepared in from a $1000 \mathrm{X}$ stock solution in DMSO. This is only about 7 times more concentrated than the ID ${ }_{50}$ of TEGDMA. If diffusion through $0.45 \mathrm{~mm}$ dentine were to dilute the maximum water-soluble concentration 571 times, as occurred with TEGDMA solubilized in ethanol in this study, then the TEGDMA concentration in the diffusate would be $0.78 \mu$ moles $/ 1$, or 85 times less than required for cytotoxicity. Therefore, on the basis of solubility, it would appear improbable that there is adequate starting concentrations for cytotoxic responses of pulpal cells to TEGDMA, except where the dentine is extremely thin or TEGDMA is applied directly to the pulp. However, dilute concentrations of resins might cause other biological effects, or work in conjunction with bacterial products to cause biological effects. And, since $\mathrm{H}_{2} \mathrm{O}_{2}$ and phenol are both much more water-soluble than the resins, then application of either of these two materials to $0.5 \mathrm{~mm}$ patent dentine is capable of causing cytotoxic responses in pulp cells.

Factors which reduce the reliability of these simple diffusion calculations in determination of risk are: (i) the positive tissue pressure when the cavity preparation is fresh (Matthews \& Pashley, 1992); (ii) the presence of blood proteins such as albumin and other molecules in the dentinal fluid which are capable of binding other molecules; (iii) the size of the fibrinogen molecule and the clotting process which are capable of reducing convective currents (but may have a limited effect on diffusion of small molecules); (iv) sorption of molecules to the walls and contents of the dentinal tubules; and (v) junctional complexes of the remaining odontoblasts (Pashley \& Pashley, 1991; Maita et al., 1991). For example, our data show that fluorescein, $\mathrm{H}_{2} \mathrm{O}_{2}$ and UDMA have lower $P$ values than would be expected from size alone (Figs. $3 \& 4$ ). We believe that fluorescein is adsorbed by the dentine. $\mathrm{H}_{2} \mathrm{O}_{2}$ is probably released more slowly than expected by the gels in which they are incorporated. We are not sure why UDMA diffused so slowly. Still unexplored are the synergistic and antagonistic effects of restorative-derived molecules with each other, bacteria-derived molecules, e.g. formyl- 
methionine-leucine-phenylalanine (fMLP) or lipopolysaccharide (LPS) or molecules of the immune system such as interleukins, cytokines or complement components. That is, even though the concentration of resin components may be too low, except with extremely thin dentine, to cause cytotoxicity by themselves within the $24-48 \mathrm{~h}$ of an in vitro assay, these same concentrations might be more toxic over several weeks in vivo, or the molecules might act in concert with other molecules to enhance or diminish deleterious effects.

Major findings in this paper were: (i) for all molecules tested, diffusion permeability was indirectly proportional to the thickness of the dentine; (ii) for many molecules, diffusion permeability was proportional to the molecular weight of the molecule; and (iii) the impossibility of diffusion of resin components, solubilized in aqueous solutions, to diffuse across a $0.5 \mathrm{~mm}$ dentine disk in sufficient concentrations to cause cytotoxicity $\left(\mathrm{ID}_{50}\right)$ to pulpal cells. However, that does not rule out that pulps which are compromised by bacterial infections or other kinds of inflammation might not be affected by lower concentrations. It also does not rule out that low concentrations might cause other biological responses. Sorption data (not published) suggest that for its size, LPS is fairly non-sorptive to the dentine disk, while smaller molecules (fMLP) are more sorptive. Although Segal et al. (1990) reported that LPS filtered through dentine (conduction) with ease, diffusion permeability in dentine disks has not been reported for LPS to our knowledge. It may be that LPS can diffuse to the pulp in concentrations sufficient to cause lymphocytic responses. It is known that LPS is a potent mitogen for $\mathrm{B}$ lymphocytes, as well as an activator of prostaglandins and the alternative complement pathway (Kumar, Cotran \& Robbins, 1992), at least in part mediated through activated macrophages. Activated macrophages synthesize and secrete several cytokines (interleukin-1, interleukin-6 and tumor necrosis factor) which mediate lymphocyte stimulation and protaglandins formation (Kunkel \& Remick, 1992). Trowbridge (1981) has reported that the mononuclear pulpal response in the pulp is the earliest response in caries, and that the acute inflammatory response is evoked at a later time. Thus, the most common long-term effect seen under restorations, the chronic lymphocytic response, may not be a reaction to resin but rather to LPS.

\section{Acknowledgment}

This research was performed with support from the United States Public Health Service, National Institute of Dental Research grant no. DE09296.

\section{References}

Avery, J.K. (1975) Response of the pulp and dentin to contact with filling materials. Journal of Dental Research, 54 (Special Issue B), B 188.

Bergenholtz, G., Cox, C.F., Loesche, W.J. \& Syed, S.A. (1982) Bacterial leakage around dental restorations: Its effect on the dental pulp. Journal of Oral Pathology, 11, 439.

Brännström, M. \& NyborG, H. (1972) Pulpal reaction to composite resin restorations. Journal of Prosthetic Dentistry, 27, 181.

Chamberlain, J. (1987) Analysis of Drugs in Biological Fluids, p. 147. CRC Press, Boca Raton.

Ciarlone, A.E., Johnson, R.D., Tomaselli, D.L., Seale, N.S. \& Pashley, D.H. (1988) The quantitative binding of tetracycline to dentin. Journal of Endodontics, 14, 494.

Cox, C.F., Bergenholtz, G., Fitzgerald, M., Heys, D.R., Heys, R.J., Avery, J.K. et al. (1982) Capping of the dental pulp mechanically exposed to the oral microflora - a 5 week observation of wound healing in the monkey. Journal of Oral Pathology, 11, 327.

Cussler, E.L. (1984) Diffusion: mass transfer in fluid systems, p. 116. Cambridge University Press, New York. 
Dahlen, G. \& Bergenholtz, G. (1980) Endotoxic activity in teeth with necrotic pulps. Journal of Dental Research, 59, 1033.

EdWALL, L. \& OLgaRT, L.G. (1972) Influence of cavity washing agents on pulpal microcirculation in the cat. Acta Odontologica Scandanavica, 30, 39.

Ferracane, J.L. (1994) Elution of leachable components from composites. Journal of Oral Rehabilitation, 21, 439.

Hanks, C.T., Craig, R.G., Diehl, M.L. \& Pashley, D.H.(1988) (Cytotoxicity of dental composites and other materials in a new in vitro device. Journal of Oral Pathology, 17, 396.

Hanks, C.T., Diehl, M.L., Craig, R.G., Makinen, P.-L. \& Pashley, D.H. (1989) Characterization of the 'in vitro pulp chamber' using the cytotoxicity of phenol. Journal of Oral Pathology and Medicine, 18, 97.

Hanks, C.T., Strawn, S.E., Wataha, J.C. \& Craig, R.G. (1991) Cytotoxic effects of resin components on cultured mammalian fibroblasts. Journal of Dental Research, 70, 1450.

Heys, R.J., Heys, D.R., Cox, C.F. \& Avery, J.K. (1982) Experimental observations on the biocompatibility of composite reins. In D.C. Smith \& D.F. Williams eds. Biocompatibility of Dental Materials III: Biocompatibility of Preventive Dental Materials and Bonding Agents, p. 131. CRC Press, Boca Raton.

Hörsted-Bindslev, P. (1987) Monkey pulp reactions to cavities treated with GLUMA Dentin Bond and restored with a microfilled composite. Scandanavian Journal of Dental Research, 95, 347.

Hume, W.R. (1985) A new technique for screening chemical toxicity to the pulp from dental restorative materials and procedures. Journal of Dental Research, 64, 1322.

Kumar, V., Cotran, R.S. \& Robbins, S.L. (1992) Basic Pathology, 5th, edn. p. 25, W.B. Saunders Co., Harcourt Brace Jovanovich, Inc., Philadelphia.

Kunkel, S.L. \& Remick, D.G. (1992) Cytokines in Health and Disease, p. 330. Marcel Dekker, Inc., New York.

Maita, E., Simpson, M.D., Tao, L., \& Pashley, D.H. (1991) Fluid and protein flux across the pulpodentine complex of the dog in vivo. Archives of Oral Biology, 36, 103.

Matthews, G. \& Pashley, D.H. (1992) Effects of pulpal pressure on inward diffusion across dentin in vitro. Journal of Dental Research, 71(Special Issue), 124.

Meryon, S.D. \& Brook, A.M. (1989) In vitro cytotoxicity of three dentine bonding agents. Journal of Dental Research, 17, 279.

Nasjleti, C.E., Castelli, W.A. \& Caffessee, R.G. (1983) Effects of composite restorations on the periodontal membrane in monkeys. Journal of Dental Research, $62,75$.

Outhwaite, W.C., McKenzie D.M. \& Pashley, D.H. (1974) A versatile split-chamber device for studying dentin permeability. Journal of Dental Research, 53, 1503.

PAshley, D.H. (1988) Consideration of dentine permeability in cytotoxicity testing. International Endodontic Journal, 21, 143.

Pashley, D.H. (1989) Dentin permeability: theory and practice. In SpÅngBerg, L.S.W. ed. Experimental Endodontics, p. 19. CRC Press, Boca Raton.

Pashley, D.H., Galloway, S.E. \& Stewart, F. (1984a) Effects of fibrinogen in vivo on dentine permeability in the dog. Archives of Oral Biology, 29, 725.

Pashley, D.H., Kepler, E.E., Williams, E.C. \& O'Meara, J.A. (1984b) The effect on dentine permeability of time following cavity preparation in dogs. Archives of Oral Biology, 29, 65.

Pashley, D.H. \& Livingston, M.J. (1978) Effect of molecular size on permeability coefficients in human dentine. Archives of Oral Biology, 23, 391.

Pashley, D.H. \& Pashley, E.L. (1991) Dentin permeability and restorative dentistry. American Journal of Dentistry, $4,5$.

Seale, N.S., McIntosh, J.E. \& Taylor, A.N. (1981) Pulpal reaction to bleaching of teeth in dogs. Pediatric Dentistry, 7, 209.

Segal, H., Stevens, R.H., Trowbridge, H. \& Pashley, D.H. (1990) Permeability of human dentin to bacterial endotoxin. Journal of Dental Research, 69 (Special Issue), 355.

Stanley, H.R., Bowen, R.L. \& Folıo, J. (1979) Compatibility of various materials with oral tissues. II: Pulp responses to composite ingredients. Journal of Dental Research, 58, 1507.

Trowdridge, H.O. (1981) Pathogenesis of pulpitis resulting from dental caries. Journal of Endodontics, 7,52 .

Varpio, M., Warfinge, J. \& Norén, J.G. (1990) Proximo-occlusal composite restorations in primary 
molars: marginal adaptation, bacterial penetration and pulpal reactions. Acta Odontologica Scandanavica, 48, 161.

Wataha, J.C., Hanks, C.T., Strawn, S.E. \& Fat, J.C. (1994) Cytotoxicity of components of resins and other dental restorative materials. Journal of Oral Rehabilitation, 21, 453. 
This document is a scanned copy of a printed document. No warranty is given about the accuracy of the copy. Users should refer to the original published version of the material. 